\title{
Implications of vitamin D deficiency in pregnancy and lactation
}

\author{
Megan L. Mulligan, BA, Shaili K. Felton, MD, Amy E. Riek, MD, and Carlos Bernal-Mizrachi, \\ MD \\ From the New York University School of Medicine, New York, NY (Ms Mulligan), and Division of \\ Endocrinology, Metabolism, and Lipid Research, Department of Medicine, Washington University \\ School of Medicine, St. Louis, MO (Drs Felton, Riek, and Bernal-Mizrachi)
}

\begin{abstract}
Vitamin D is an essential fat soluble vitamin and a key modulator of calcium metabolism in children and adults. Because calcium demands increase in the third trimester of pregnancy, vitamin D status becomes crucial for maternal health, fetal skeletal growth, and optimal maternal and fetal outcomes. Vitamin D deficiency is common in pregnant women (5-50\%) and in breastfed infants (10-56\%), despite the widespread use of prenatal vitamins, because these are inadequate to maintain normal vitamin D levels ( $32 \mathrm{ng} / \mathrm{mL}$ ). Adverse health outcomes such as preeclampsia, low birthweight, neonatal hypocalcemia, poor postnatal growth, bone fragility, and increased incidence of autoimmune diseases have been linked to low vitamin D levels during pregnancy and infancy. Studies are underway to establish the recommended daily doses of vitamin $\mathrm{D}$ in pregnant women. This review discusses vitamin D metabolism and the implications of vitamin $\mathrm{D}$ deficiency in pregnancy and lactation.
\end{abstract}

\section{Keywords}

lactation; pregnancy; vitamin D deficiency

Vitamin D deficiency has long been associated with poor bone development and has been identified as the cause of rickets. Although the incidence of rickets has declined with the current daily recommendations of vitamin $\mathrm{D}$ intake, the prevalence and additional consequences of low serum vitamin D levels have not been recognized until recently. ${ }^{1,2}$ The measurement of serum vitamin D in pregnancy has helped researchers establish the prevalence of vitamin D deficiency and elucidate adverse maternal and fetal outcomes associated with it. ${ }^{3}$ Prevention of these diseases and reduction of the risk for childhood illnesses that are linked to early vitamin D deficiency are possible with greater understanding of vitamin D physiologic components, risk factors for vitamin D deficiency, and methods of supplementation to attain optimal levels in pregnant and lactating women.

\section{Vitamin D physiologic components}

Vitamin D is a prohormone that is derived from cholesterol. The nutritional forms of vitamin $\mathrm{D}$ include $\mathrm{D}_{3}$ (cholecalciferol), which is generated in the skin of humans and animals, and vitamin $\mathrm{D}_{2}$ (ergocalciferol), which is derived from plants; both forms can be absorbed in the gut and used by humans. Controversy exists as to whether $D_{2}$ or $D_{3}$ is more effective in maintaining circulating levels of vitamin D in nonpregnant individuals, and specific data

(C) 2010 Mosby, Inc. All rights reserved.

Reprints: Carlos Bernal-Mizrachi, MD, Washington University School of Medicine, Campus Box 8127, 660 South Euclid Ave., St. Louis, MO 63110.cbernal@dom.wustl.edu. 
during pregnancy is unknown. ${ }^{4,5}$ In this review when we refer to vitamin $\mathrm{D}$, we imply either vitamin $\mathrm{D}_{2}$ or $\mathrm{D}_{3}$. Vitamin $\mathrm{D}$ occurs naturally in fish and some plants but is not found in significant amounts in meat, poultry, dairy products (without fortification), or the most commonly eaten fruits and vegetables. The Food and Nutrition Board's current recommendation for adequate intake of vitamin D is $200 \mathrm{IU} / \mathrm{d}$ for both pregnant and nonpregnant individuals aged $0-50$ years. ${ }^{6}$ Wild salmon $(3.5 \mathrm{oz})$ provides $600-1000 \mathrm{IU}$; farmed salmon has approximately $25 \%$ of this amount per serving. ${ }^{7}$ The same amount of mackerel, sardines, or tuna fish provides 200-300 IU. Cod liver oil (1 tsp) provides 600$1000 \mathrm{IU}$. One of the few plant sources of vitamin D is shiitake mushrooms, which provide 1600 IU. In the United States, the major dietary sources of vitamin D are fortified foods. For example, 8 ounces of fortified milk, orange juice, or yogurt, 3 ounces of fortified cheese, or a serving of fortified breakfast cereal each provides $100 \mathrm{IU}$ of vitamin D (Table 1). ${ }^{2,8}$ However, the relative contribution of dietary vitamin D is low in humans, compared with endogenous production from sunlight. ${ }^{9,10}$

Exposure to sunlight, especially ultraviolet B (UVB) photons, initiates conversion in the skin of provitamin $\mathrm{D}_{3}$ to previtamin $\mathrm{D}_{3}$, which binds to vitamin $\mathrm{D}$ binding protein for transport in the circulation and is rapidly stored in fat or metabolized in the liver. ${ }^{10}$ Several hepatic cytochrome $P-450$ enzymes have been shown to 25 -hydroxylate vitamin D compounds. This process is regulated poorly, so serum levels of 25-hydroxy vitamin D $(25[\mathrm{OH}] \mathrm{D})$ increase in proportion to vitamin $\mathrm{D}$ synthesis and intake, which represents the best indicator of vitamin D status. ${ }^{11}$

The second step in vitamin $\mathrm{D}$ activation is the formation of $1 a, 25$ di-hydroxyvitamin $\mathrm{D}$ $\left(1,25[\mathrm{OH}]_{2} \mathrm{D}\right.$ or active vitamin $\left.\mathrm{D}\right)$ by $1 a$-hydroxylase, which occurs mainly in the kidney. ${ }^{12}$ Numerous tissues (including placenta, prostate, breast, colon, lung, bone, parathyroid, pancreas, immune system, and vascular wall) express the vitamin D receptor and the $1 a$ hydroxylase and are able to transform $25(\mathrm{OH}) \mathrm{D}$ to its active hormonal form. ${ }^{13-16}$ Locally produced $1,25(\mathrm{OH})_{2} \mathrm{D}$ serves as an autocrine/paracrine factor that is fundamental for cellspecific proliferation, differentiation, and function early in life. ${ }^{17}$

The efficiency of vitamin D synthesis depends on a variety of factors, most importantly the number of UVB photons that penetrate the epidermis. More time spent indoors and widespread use of sunscreen have resulted in reduced sun exposure and less vitamin D production. Latitude and season of the year also determine both the quantity and quality of UVB radiation. Skin production of vitamin D declines after August and virtually ceases from November until March at latitudes of $>42^{\circ} \mathrm{N}$ (Boston). ${ }^{18}$ Other factors, such as aging and increased melanin in dark-skinned people, reduce the efficiency by which sunlight converts provitamin $\mathrm{D}$, thereby decreasing vitamin D synthesis (Table 2). ${ }^{19}$ Plasma $25(\mathrm{OH}) \mathrm{D}$ levels during the winter therefore depend on vitamin D intake, which is largely from food additives or supplements.

As an individual becomes deficient in vitamin $\mathrm{D}$, intestinal calcium and phosphorous absorption decrease; serum ionized calcium levels drop, and synthesis of parathyroid hormone $(\mathrm{PTH})$ is stimulated. Increased plasma PTH maintains serum calcium in the normal range by enhancing renal production of $1,25(\mathrm{OH})_{2} \mathrm{D}$, increasing bone turnover, accelerating bone loss, and promoting tubular calcium reabsorption and phosphate excretion. Increased $1,25(\mathrm{OH})_{2} \mathrm{D}$ induces intestinal calcium and phosphorus absorption and stimulates osteoclast activity, thereby increasing calcium and phosphorous availability in the blood (Figure). ${ }^{17,20}$

\section{Vitamin D and calcium metabolism in pregnancy}

During pregnancy and lactation, significant changes in maternal vitamin $\mathrm{D}$ and calcium metabolism occur to provide the calcium that is needed for fetal bone mineral accretion. 
During the first trimester, the fetus accumulates $2-3 \mathrm{mg} / \mathrm{d}$ in the skeleton; however, this rate of accumulation doubles in the last trimester. ${ }^{21}$ The body of a pregnant woman adapts to fetal requirements by increasing calcium absorption in early pregnancy, with maximal absorption in the last trimester. ${ }^{22,23}$ Along with the transfer of calcium to the fetus, the increased intestinal absorption is balanced by enhancing urinary calcium excretion, thereby keeping serum ionized calcium stable throughout pregnancy. ${ }^{24-26}$ In several small studies, $1,25(\mathrm{OH})_{2} \mathrm{D}$ levels in plasma increased by 2 -fold early in pregnancy, compared with prepregnancy values, reached a maximum in the third trimester, and returned to normal or below normal during lactation. ${ }^{23,27,28}$ Plasma 25(OH)D levels do not change, unless intake or synthesis changes. ${ }^{29}$ The increased $1,25(\mathrm{OH})_{2} \mathrm{D}$ synthesis depends on the acceleration of $1 a$-hydroxylation in the maternal kidneys and possibly increased placental and decidual $1 a$ hydroxylase activity. ${ }^{30-32}$ The stimulus to increase synthesis of $1,25(\mathrm{OH})_{2} \mathrm{D}$ is not clear because serum PTH levels do not change during pregnancy. A potential signal for placental calcium transfer and placental synthesis of active vitamin D is PTH-related peptide (PTHrP), which is produced in fetal parathyroid glands and the placental tissues and increases placental synthesis of active vitamin D. ${ }^{33-36}$ PTHrP potentially might reach the maternal circulation. Acting through the PTH/PTHrP receptor in kidney and bone, PTHrP could mediate the increased $1,25(\mathrm{OH})_{2} \mathrm{D}$ and help to regulate calcium and PTH levels during human pregnancy. ${ }^{37}$ The profound increase in intestinal calcium absorption cannot be explained solely by the increased $1,25(\mathrm{OH})_{2} \mathrm{D}$ because the increased calcium absorption occurs before $1,25(\mathrm{OH})_{2} \mathrm{D}$ levels increase and occurs in rodents even in the absence of vitamin D receptor. ${ }^{38}$

Other signals that regulate active calcium homeostasis and vitamin D synthesis during pregnancy include prolactin, placental lactogen, calcitonin, osteoprotegerin, and estrogen. Prolactin increases throughout pregnancy and remains above normal after delivery. Placental lactogen increases throughout pregnancy but returns to prepregnancy values after delivery. Prolactin and placental lactogen's roles have not been clearly elucidated in calcium metabolism. It is thought that they both contribute to increase calcium absorption from the intestine, decrease urinary calcium excretion, and stimulate production of PTHrP and $1,25(\mathrm{OH})_{2} \mathrm{D} .{ }^{39,40}$ Calcitonin increases 2 -fold in the second trimester, compared with the first trimester, but then declines slightly at term. It has been hypothesized that the rise in serum calcitonin protects the maternal skeleton from excessive resorption of calcium. ${ }^{41}$

Osteoprotegerin levels have also been shown to be higher in the third trimester of pregnancy than the first trimester of pregnancy. The fetal skeleton contains $30 \mathrm{~g}$ of calcium, most of which is deposited during the third trimester of pregnancy. It can be inferred that osteoprotegerin, which acts as a decoy receptor for RANK ligand and inhibits osteoclast activity, may also protect the maternal skeleton from excessive resorption of calcium. ${ }^{42,43}$ Lactation is a time of relative estrogen deficiency because of elevated prolactin levels that suppress the release of gonadotropins and, in turn, estrogen and perhaps stimulate the release of PTHrP. Estrogen deficiency leads to bone resorption and suppression of PTH levels. PTHrP levels are elevated and act as a surrogate for PTH, thereby allowing continued absorption of calcium from the urine and bone resorption. ${ }^{38,44}$

\section{Classification of vitamin D status}

Vitamin D status is usually estimated by measuring the level of plasma $25(\mathrm{OH}) \mathrm{D}$. Evidence of $25(\mathrm{OH}) \mathrm{D}$ concentrations of $44-70 \mathrm{ng} / \mathrm{mL}$ observed in healthy outdoor workers (such as farmers and lifeguards) suggest an optimal healthy level that is far above the levels that are reported to prevent rickets and osteomalacia. ${ }^{45,46}$ Studies that have evaluated the correlation between vitamin D levels and intestinal calcium absorption, maximal PTH suppression, bone fracture prevention, and bone turnover have helped to develop a classification of stages for vitamin D status in nonpregnant adults (Table 3) that indicate that levels of $>32 \mathrm{ng} / \mathrm{mL}$ 
are required for adequacy. ${ }^{47,48}$ These stages correlate with maternal and fetal outcomes, which suggests that they also apply in pregnancy and during lactation. ${ }^{49}$

\section{Prevalence of vitamin $D$ deficiency in pregnancy}

Vitamin D deficiency during pregnancy is a worldwide epidemic; studies have reported a prevalence that ranges from 18-84\%, depending on the country of residence and local clothing customs. ${ }^{50-54}$ In the United States, vitamin D deficiency is estimated to occur in 5$50 \%$ of pregnant women. ${ }^{55,56}$ African American women have a much higher risk of vitamin D deficiency, compared with other women because of increased skin pigmentation and low dietary intake. ${ }^{57}$ Bodnar et al ${ }^{3}$ reported the prevalence of vitamin D deficiency and insufficiency in 200 white and 200 black pregnant women and in the cord blood of their neonates. In African American pregnant women, vitamin D deficiency and insufficiency occurred in $29.2 \%$ and $54.1 \%$, respectively, compared with $5 \%$ and $42.1 \%$ of white pregnant women. Interestingly, $90 \%$ of study participants reported that they were taking prenatal vitamins. At delivery, vitamin D deficiency and insufficiency occurred in $45.6 \%$ and $46.8 \%$ of black neonates, respectively, compared with $9.7 \%$ and $56.4 \%$ of white neonates.

\section{Maternal effects of vitamin $D$ deficiency}

Preeclampsia and hypertensive disorders complicate 3-10\% of pregnancies in the United States and contribute to maternal and neonatal morbidity and deaths. ${ }^{58,59}$ Previous studies have shown that women with preeclampsia have lower urinary calcium excretion, lower ionized calcium levels, higher PTH levels, and lower $1,25(\mathrm{OH})_{2}$ D levels, compared with normotensive pregnant control subjects. ${ }^{60}$ Low plasma calcium levels induce several common mechanisms that are associated with hypertension, such as increasing renal renin and PTH levels. ${ }^{61,62}$ It is thought that placental defects that cause decreased synthesis of active vitamin D could be a key event in the development of this disease by contributing to decreased calcium levels. ${ }^{63}$

A recent study in 274 pregnant women showed that vitamin D deficiency at or before week 22 of gestation was an independent predictor of preeclampsia and low vitamin D status in the neonate. Patients with $25(\mathrm{OH}) \mathrm{D}$ levels $<15 \mathrm{ng} / \mathrm{mL}$ had a 5 -fold increase in the risk of pre-eclampsia, despite receiving prenatal vitamins (adjusted odds ratio, 5.0; 95\% confidence interval, 1.7-14.1). ${ }^{64}$ In addition, 2 interventional trials have reported the effects of vitamin D plus calcium supplementation on blood pressure outcomes. One study showed that halibut liver oil supplementation (900 IU of vitamin D per day) beginning at week 20 of gestation decreased the odds of preeclampsia by $32 \%$, but these women were receiving a dietary supplement that contained other vitamins, minerals, and fish oil in addition to the halibut liver oil. ${ }^{64} \mathrm{~A}$ second randomized controlled clinical trial demonstrated that vitamin D (1200 IU/d) plus calcium $(375 \mathrm{mg} / \mathrm{d})$ started at 20-24 weeks of gestation significantly reduced blood pressure $(P<.001)$, compared with placebo treatment, but the difference in the incidence of preeclampsia between the 2 groups was not statistically significant. ${ }^{65,66}$

It is hypothesized that low calcium levels, perhaps through vitamin D mediation, ultimately lead to the development of preeclampsia. Women in the United States, however, are not at risk for calcium deficiency ${ }^{67}$ The Calcium for Pre-eclampsia Prevention study, which was conducted in the United States, showed no decrease in the risk of the development of preeclampsia with calcium supplementation. An international study supplemented calcium to women with low calcium intakes $(<600 \mathrm{mg} / \mathrm{d})$ and found no reduction in the rate of preeclampsia but did show a reduction in the severity of the disease. ${ }^{68}$ Based on results of the aforementioned trials, the exact role that calcium and vitamin D play in the development and severity of pre-eclampsia is still unclear. A large interventional trial is needed to further 
elucidate whether calcium supplementation, vitamin D supplementation, or both can reduce the incidence of this disease.

\section{Fetal and newborn effects of gestational vitamin D deficiency}

\section{Infant size}

Several studies have reported an association between infant size and vitamin D status. In a study in 449 Iranian pregnant women, higher mean birth length was found at delivery in babies from mothers who received the recommended dietary allowance of calcium and vitamin $\mathrm{D}$. The incidence of low birthweight was significantly lower in newborn infants from mothers who received the recommended doses of calcium and vitamin D. ${ }^{69}$ In 2251 pregnant women from the Camden study, a prospective analysis of the effects of maternal nutrition and growth in generally healthy pregnant women in the United States, total intake of vitamin $\mathrm{D}$ was a significant predictor of infant birthweight when adjusted for gestational duration. After data adjustments for energy intake, other nutrients (calcium, iron, folate, protein, zinc), and other potential confounding variables, a significant direct trend between birth-weight and vitamin D intake persisted. In addition, pregnant women with vitamin D intakes $<200 \mathrm{IU} / \mathrm{d}$ had infants with birthweights that were $60 \mathrm{~g}$ below women with vitamin D intakes at or above $200 \mathrm{IU} / \mathrm{d} .{ }^{70}$ However, studies that account for confounding variables (such as ethnicity, nutritional status, and sunlight exposure) are needed.

Initial randomized controlled trials of vitamin D supplementation in British mothers of Asian descent suggest a greater incidence of small-for-gestational-age infants born to mothers who received placebo than to mothers who received $1000 \mathrm{IU}$ of vitamin D per day during the final trimester of pregnancy. ${ }^{71,72}$ Follow-up data from the same group of patients showed that infants from the maternal placebo group gained less weight and had a lower rate of linear growth in the first year of life than infants from the supplemented group. ${ }^{73} \mathrm{In}$ contrast, a randomized trial was conducted in France in 3 groups of pregnant women in the third trimester: 1 group received 200,000 IU of vitamin D in a single dose, 1 group received $1000 \mathrm{IU}$ of vitamin D daily, and 1 group served as the control. No differences in birthweight were found among groups. ${ }^{74}$ However, these studies are based on small sample sizes, which makes interpretation difficult.

Recent studies with larger patient samples suggest that both milk consumption and vitamin $\mathrm{D}$ intake are predictors of infant size. One study showed that, for every cup of milk consumed per day by the mother, there is an associated increase in infant birthweight of $41 \mathrm{~g}$ and that every microgram of daily vitamin $\mathrm{D}$ intake correlates with an increased birth-weight of 11 g. ${ }^{75}$ A study of $>50,000$ women from the Netherlands showed that those women who drank a significant amount of milk ( $\ 6$ glasses per day) had an odds ratio of 1.59 for having a large-for-gestational age baby. Inversely, women who consumed no milk during their pregnancy had a significantly increased risk of having a small-for-gestational-age baby. ${ }^{76}$ However, multiple confounding factors could be implicated for the milk effects on gestational baby size. Larger interventional, randomized control trials to address birth size and vitamin D are underway.

\section{Skeletal development}

The importance of vitamin $\mathrm{D}$ for fetal and infant skeletal development has long been recognized. Poor skeletal mineralization in utero that is induced by vitamin D deficiency may manifest as congenital rickets, craniotabes, or osteopenia in newborn infants. Congenital rickets is rare, typically occurring only in infants born to mothers with severe vitamin D deficiency and osteomalacia (Table 2). ${ }^{77,78}$ In full-term infants, impaired fetal bone ossification correlated with maternal vitamin D deficiency. ${ }^{79,80}$ Interestingly, reduced concentrations of $25(\mathrm{OH}) \mathrm{D}$ in mothers during late pregnancy was associated with reduced 
whole-body and lumbar-spine bone-mineral content in their children at age 9 years. ${ }^{81}$

Maternal vitamin D deficiency has also been associated with craniotabes or larger

fontanelles in full-term infants, which is consistent with impaired ossification of the skull; however, these findings are controversial. ${ }^{82,83}$

\section{Vitamin D deficiency during lactation}

In the first 6-8 weeks of postnatal life, the vitamin D status of a neonate is dependent largely on vitamin $\mathrm{D}$ that is acquired through placental transfer in utero, as evidenced by the direct linear relationship between maternal and cord blood levels of 25(OH)D. ${ }^{84}$ In most infants, vitamin D stores acquired from the mother are depleted by approximately 8 weeks of age. ${ }^{85}$ Thereafter, vitamin D is derived from diet, sunlight, and supplementation. In general, formula-fed babies receive adequate vitamin $\mathrm{D}$ because it is added to all formulas in the United States in amounts of $400 \mathrm{IU}$ of vitamin D per liter. In contrast, babies who are exclusively breastfed are at higher risk for vitamin D deficiency. ${ }^{86}$ Human milk contains a very low concentration of vitamin D (approximately 20-60 IU/L), which represents 1.5-3\% of the maternal level. ${ }^{87}$ This concentration is not sufficient to maintain an optimal vitamin D level in the baby if exposure to sunlight is limited.

Breast-fed infants from vitamin D- deficient mothers occasionally manifest life-threatening conditions such as hypocalcemic seizures and dilated cardiomyopathy. ${ }^{78,88-91}$ In the United Kingdom and Ireland, the incidence of rickets-associated heart failure is estimated at 2.7 cases per year. ${ }^{90}$ A study from Canada between 2002 and 2004 identified the incidence of vitamin D- deficient rickets in children $\leq 8$ years old at 2.9 cases per $100,000,19 \%$ of whom had hypocalcemic seizures overall, with seizures being the complaint in nearly onehalf of infants <1 year old. ${ }^{92}$ In another case series from London between 1996 and 2001, severe vitamin D deficiency was identified in 65 children $<16$ years old, $25 \%$ of whom had seizures. ${ }^{93}$ Recent reports of rickets in breast-fed infants with a lack of sun exposure are concerning. ${ }^{94}$ All of these conditions respond to calcium and vitamin D replacement or exposure to sunlight. Therefore, as of November 2008, the American Academy of Pediatrics recommends that exclusively breast-fed infants should receive supplements that contain 400 IU of vitamin D daily, beginning shortly after birth and continuing throughout childhood and adolescence. ${ }^{1}$ Supplementation has traditionally been available only in liquid formulations that are administered with a dropper and that include vitamins $\mathrm{A}$ and $\mathrm{C}$, but now liquid vitamin $\mathrm{D}$ is available alone without other vitamins. Recent studies show that maternal vitamin D intake of 4000 IU daily during lactation in vitamin D-in-sufficient mothers enhances vitamin D levels in breast milk and may be a potential therapeutic intervention to prevent vitamin D deficiency-related complications in both women and their breast-fed infants. ${ }^{95}$

\section{Childhood illness and gestational vitamin D deficiency}

\section{Asthma}

Multiple biologic actions suggest a correlation between vitamin D deficiency and the asthma epidemic. ${ }^{96}$ Vitamin D signaling pathways and receptor polymorphisms ${ }^{97-99}$ may have effects on $\mathrm{Th}_{1}-\mathrm{Th}_{2}$ imbalance, ${ }^{97,100,101}$ smooth muscle contraction, ${ }^{102,103}$ airway inflammation, prostaglandin regulation, and airway remodeling, all of which can impact asthma control. In animal models, vitamin D regulates lung growth in utero. ${ }^{104} \mathrm{Clinical}$ studies indicate an inverse association between vitamin $\mathrm{D}$ intake during gestation and wheezing in their children during the first years of life. ${ }^{105,106}$ Post-hoc analysis of serum samples of asthmatic children from the Childhood Asthma Management Program study showed that approximately $35 \%$ of patients had levels of vitamin D $<30 \mathrm{ng} / \mathrm{mL}$ and that 
these children had lower lung function and greater risks for exacerbations than those with levels $>30 \mathrm{ng} / \mathrm{mL}{ }^{107}$

\section{Type 1 diabetes mellitus (type 1 DM)}

The Diabetes Autoimmunity Study in the Young reported that autoantibodies to islet cells are correlated inversely with maternal dietary vitamin D intake during pregnancy. ${ }^{108}$ More direct evidence of this correlation has come from the Europe and Diabetes study in which vitamin D supplementation during the first year of life decreased the risk of the development of type 1 DM (odds ratio, 0.67; 95\% confidence interval, 0.5-0.8). ${ }^{109,110}$ In a Finnish study, children who received $2000 \mathrm{IU}$ of vitamin D per day during the first year of life had an $80 \%$ reduction in the risk of the development of type $1 \mathrm{DM}$ during a follow-up period of 30 years. In contrast, children who were vitamin D-deficient or who were suspected to have rickets at 1 year had a 2.4-fold increased risk of the development of type $1 \mathrm{DM}$. The high doses of vitamin $\mathrm{D}$ that were used in this study clearly establish the preventive effects of this vitamin in the development of type 1 DM. ${ }^{111}$

\section{Recommendations for monitoring and replacement}

Vitamin D is important to maternal health, fetal development, and postnatal life. Current prenatal care does not include the monitoring of vitamin D levels, which is an unfortunate oversight because deficiency is easily treated. On average, daily vitamin D supplements of 1000-2000 IU cost \$1-2 per month. Women with $\geq 1$ risk factors for vitamin D deficiency (Table 2) should have a plasma 25(OH)D level drawn at the beginning of gestation and at mid pregnancy. The recommended target range for nonpregnant adults is $32-100 \mathrm{ng} / \mathrm{mL}$ (80-250 nmol/L), which appears to be a safe range during pregnancy. In the United States, the current recommendation for vitamin D intake during pregnancy is $200-400 \mathrm{IU} / \mathrm{d}$. However, a previous study has shown that prenatal supplements that contain $400 \mathrm{IU}$ of vitamin $\mathrm{D}$ are not adequate to achieve normal vitamin D levels in pregnant women or their infants. ${ }^{112}$ Even more concerning, studies of supplementation with $800-1600$ IU vitamin D per day during the last trimester of pregnancy in women with $25(\mathrm{OH}) \mathrm{D}$ levels $<15 \mathrm{ng} / \mathrm{mL}$ showed that vitamin D levels increased from $5.8 \mathrm{ng} / \mathrm{mL}$ to a mere $11 \mathrm{ng} / \mathrm{mL}{ }^{74,113,114}$ Therefore, supplemental vitamin D in doses that exceed 1000 IU per day (2000-10,000 IU/ d) may be required to achieve a normal concentration of circulating vitamin D in severely deficient patients. Studies with $2000-4000$ IU daily of vitamin D supplementation in nonpregnant women have shown these amounts to be safe and effective at achieving normal vitamin D levels. ${ }^{115}$ Studies in pregnant women are underway in the United States that use vitamin D at doses of 2000 IU and 4000 IU daily to establish vitamin D recommendations during pregnancy.

\section{Comment}

Recent evidence demonstrates that the prevalence of vitamin D deficiency in the general population and in women of child-bearing age is surprisingly high. However, the influence of vitamin D deficiency on calcium metabolism during pregnancy has not been wellcharacterized. Vitamin D deficiency is known to be associated with an increased prevalence of preeclampsia, which a common cause of increased mortality rates in pregnancy. In children, it is also associated with small infant size and the development of common childhood diseases, such as asthma and type $1 \mathrm{DM}$. Current recommendations for daily vitamin D intake (200 IU) are inadequate to maintain serum levels of $25(\mathrm{OH}) \mathrm{D}$ in the normal range during pregnancy and lactation. Further studies are needed to determine the serum levels and the degree of supplementation that is required to optimize maternal and fetal outcomes. However, because vitamin D supplementation is simple and cost-effective 
with a low likelihood of toxicity, we recommend increased supplementation in all pregnant women to keep serum levels of $25(\mathrm{OH}) \mathrm{D}$ in the normal range for adults $(>32 \mathrm{ng} / \mathrm{mL})$.

\section{Acknowledgments}

Financial support was provided by the American Diabetes Association (Grant 7-08-CR-08); Washington University; the Diabetes Research and Training Center (Grant P60 DK20579); and the David M. and Paula L. Kipnis Scholar in Medicine, Washington University School of Medicine.

\section{References}

1. Wagner CL, Greer FR. Prevention of rickets and vitamin D deficiency in infants, children, and adolescents. Pediatrics. 2008; 122:1142-52. [PubMed: 18977996]

2. Holick MF. Vitamin D deficiency. N Engl J Med. 2007; 357:266-81. [PubMed: 17634462]

3. Bodnar LM, Simhan HN, Powers RW, Frank MP, Cooperstein E, Roberts JM. High prevalence of vitamin D insufficiency in black and white pregnant women residing in the northern United States and their neonates. J Nutr. 2007; 137:447-52. [PubMed: 17237325]

4. Trang HM, Cole DE, Rubin LA, Pierratos A, Sui S, Vieth R. Evidence that vitamin D3 increases serum 25-hydroxyvitamin D more efficiently than does vitamin D2. Am J Clin Nutr. 1998; 68:8548. [PubMed: 9771862]

5. Holick MF, Biancuzzo RM, Chen TC, et al. Vitamin D2 is as effective as vitamin D3 in maintaining circulating concentrations of 25-hydroxyvitamin D. J Clin Endocrinol Metab. 2008; 93:677-81. [PubMed: 18089691]

6. Food and Nutrition Board, Institute of Medicine. Dietary reference intakes (DRIs): recommended intakes for individuals. Washington, DC: National Academies of Sciences; 2004.

7. Lu Z, Chen TC, Zhang A, et al. An evaluation of the vitamin D3 content in fish: is the vitamin D content adequate to satisfy the dietary requirement for vitamin D? J Steroid Biochem Mol Biol. 2007; 103:642-4. [PubMed: 17267210]

8. Ko JA, Lee BH, Lee JS, Park HJ. Effect of UV-B exposure on the concentration of vitamin D2 in sliced shiitake mushroom (Lentinus edodes) and white button mushroom (Agaricus bisporus). J Agric Food Chem. 2008; 56:3671-4. [PubMed: 18442245]

9. Webb AR, DeCosta BR, Holick MF. Sunlight regulates the cutaneous production of vitamin D3 by causing its photodegradation. J Clin Endocrinol Metab. 1989; 68:882-7. [PubMed: 2541158]

10. Holick MF, Frommer JE, McNeill SC, Richtand NM, Henley JW, Potts JT Jr. Photometabolism of 7-dehydrocholesterol to previtamin D3 in skin. Biochem Biophys Res Commun. 1977; 76:107-14. [PubMed: 194588]

11. Lips, P. How to define normal values for serum concentrations of 25-hydroxyvitamin D? An overview. In: Feldman, D.; Pike, JW.; Glorieux, FH., editors. Vitamin D. 2. Vol. 2. Boston: Elsevier Academic Press; 2005. p. 1019-28.

12. Fraser DR, Kodicek E. Unique biosynthesis by kidney of a biological active vitamin D metabolite. Nature. 1970; 228:764-6. [PubMed: 4319631]

13. Zehnder D, Evans KN, Kilby MD, et al. The ontogeny of 25-hydroxyvitamin D(3) 1alphahydroxylase expression in human placenta and decidua. Am J Pathol. 2002; 161:105-14. [PubMed: 12107095]

14. Schwartz GG, Whitlatch LW, Chen TC, Lokeshwar BL, Holick MF. Human prostate cells synthesize 1,25-dihydroxyvitamin D3 from 25-hydroxyvitamin D3. Cancer Epidemiol Biomarkers Prev. 1998; 7:391-5. [PubMed: 9610788]

15. Zehnder D, Bland R, Walker EA, et al. Expression of 25-hydroxyvitamin D3-1alpha-hydroxylase in the human kidney. J Am Soc Nephrol. 1999; 10:2465-73. [PubMed: 10589683]

16. Zehnder D, Bland R, Williams MC, et al. Extrarenal expression of 25-hydroxyvitamin d(3)-1 alpha-hydroxylase. J Clin Endocrinol Metab. 2001; 86:888-94. [PubMed: 11158062]

17. Dusso AS, Brown AJ, Slatopolsky E. Vitamin D. Am J Physiol Renal Physiol. 2005; 289:F8-28. [PubMed: 15951480] 
18. Webb AR, Kline L, Holick MF. Influence of season and latitude on the cutaneous synthesis of vitamin D3: exposure to winter sunlight in Boston and Edmonton will not promote vitamin D3 synthesis in human skin. J Clin Endocrinol Metab. 1988; 67:373-8. [PubMed: 2839537]

19. Holick MF. McCollum Award Lecture, 1994: vitamin D: new horizons for the 21st century. Am J Clin Nutr. 1994; 60:619-30. [PubMed: 8092101]

20. Omdahl JL, Gray RW, Boyle IT, Knutson J, DeLuca HF. Regulation of metabolism of 25hydroxycholecalciferol by kidney tissue in vitro by dietary calcium. Nat New Biol. 1972; 237:634. [PubMed: 4338043]

21. Abrams SA. In utero physiology: role in nutrient delivery and fetal development for calcium, phosphorus, and vitamin D. Am J Clin Nutr. 2007; 85:604S-7S. [PubMed: 17284763]

22. Ritchie LD, Fung EB, Halloran BP, et al. A longitudinal study of calcium homeostasis during human pregnancy and lactation and after resumption of menses. Am J Clin Nutr. 1998; 67:693701. [PubMed: 9537616]

23. Cross NA, Hillman LS, Allen SH, Krause GF, Vieira NE. Calcium homeostasis and bone metabolism during pregnancy, lactation, and post-weaning: a longitudinal study. Am J Clin Nutr. 1995; 61:514-23. [PubMed: 7872214]

24. Gertner JM, Coustan DR, Kliger AS, Mallette LE, Ravin N, Broadus AE. Pregnancy as state of physiologic absorptive hypercalciuria. Am J Med. 1986; 81:451-6. [PubMed: 3755867]

25. Black AJ, Topping J, Durham B, Farquharson RG, Fraser WD. A detailed assessment of alterations in bone turnover, calcium homeostasis, and bone density in normal pregnancy. J Bone Miner Res. 2000; 15:557-63. [PubMed: 10750571]

26. Pitkin RM, Reynolds WA, Williams GA, Hargis GK. Calcium metabolism in normal pregnancy: a longitudinal study. Am J Obstet Gynecol. 1979; 133:781-90. [PubMed: 434021]

27. Bikle DD, Gee E, Halloran B, Haddad JG. Free 1,25-dihydroxyvitamin D levels in serum from normal subjects, pregnant subjects, and subjects with liver disease. J Clin Invest. 1984; 74:196671. [PubMed: 6549014]

28. Wilson SG, Retallack RW, Kent JC, Worth GK, Gutteridge DH. Serum free 1,25dihydroxyvitamin $\mathrm{D}$ and the free 1,25-dihydroxyvitamin $\mathrm{D}$ index during a longitudinal study of human pregnancy and lactation. Clin Endocrinol (Oxf). 1990; 32:613-22. [PubMed: 2364565]

29. Ardawi MS, Nasrat HA, BA'Aqueel HS. Calcium-regulating hormones and parathyroid hormonerelated peptide in normal human pregnancy and postpartum: a longitudinal study. Eur J Endocrinol. 1997; 137:402-9. [PubMed: 9368509]

30. Turner M, Barre PE, Benjamin A, Goltzman D, Gascon-Barre M. Does the maternal kidney contribute to the increased circulating 1,25-di-hydroxyvitamin D concentrations during pregnancy? Miner Electrolyte Metab. 1988; 14:246-52. [PubMed: 3211093]

31. Gray TK, Lowe W, Lester GE. Vitamin D and pregnancy: the maternal-fetal metabolism of vitamin D. Endocr Rev. 1981; 2:264-74. [PubMed: 7023922]

32. Hewison M, Zehnder D, Chakraverty R, Adams JS. Vitamin D and barrier function: a novel role for extrarenal 1 alpha-hydroxylase. Mol Cell Endocrinol. 2004; 215:31-8. [PubMed: 15026172]

33. Barlet JP, Davicco MJ, Coxam V. Synthetic parathyroid hormone-related peptide (1-34) fragment stimulates placental calcium transfer in ewes. J Endocrinol. 1990; 127:33-7. [PubMed: 2103576]

34. Sowers MF, Hollis BW, Shapiro B, et al. Elevated parathyroid hormone-related peptide associated with lactation and bone density loss. JAMA. 1996; 276:549-54. [PubMed: 8709404]

35. Dobnig H, Kainer F, Stepan V, et al. Elevated parathyroid hormone-related peptide levels after human gestation: relationship to changes in bone and mineral metabolism. J Clin Endocrinol Metab. 1995; 80:3699-707. [PubMed: 8530622]

36. Hosking DJ. Calcium homeostasis in pregnancy. Clin Endocrinol (Oxf). 1996; 45:1-6. [PubMed: 8796131]

37. Gallacher SJ, Fraser WD, Owens OJ, et al. Changes in calciotropic hormones and biochemical markers of bone turnover in normal human pregnancy. Eur J Endocrinol. 1994; 131:369-74. [PubMed: 7921225]

38. Kovacs CS. Vitamin D in pregnancy and lactation: maternal, fetal, and neonatal outcomes from human and animal studies. Am J Clin Nutr. 2008; 88:520S-8S. [PubMed: 18689394] 
39. Spanos E, Colston KW, Evans IM, Galante LS, Macauley SJ, Macintyre I. Effect of prolactin on vitamin D metabolism. Mol Cell Endocrinol. 1976; 5:163-7. [PubMed: 955248]

40. Takeuchi K, Morikawa H, Ueda Y, Mochizuki M. Studies on the effects of placental lactogen on calcium metabolism during pregnancy. Nippon Naibunpi Gakkai Zasshi. 1988; 64:1175-86. [PubMed: 3220151]

41. Taylor TG, Lewis PE, Balderstone O. Role of calcitonin in protecting the skeleton during pregnancy and lactation. J Endocrinol. 1975; 66:297-8. [PubMed: 1172522]

42. Hong JS, Santolaya-Forgas J, Romero R, et al. Maternal plasma osteoprotegerin concentration in normal pregnancy. Am J Obstet Gynecol. 2005; 193:1011-15. [PubMed: 16157103]

43. Uemura H, Yasui T, Kiyokawa M, et al. Serum osteoprotegerin/osteoclastogenesis-inhibitory factor during pregnancy and lactation and the relationship with calcium-regulating hormones and bone turnover markers. J Endocrinol. 2002; 174:353-9. [PubMed: 12176675]

44. Baksi SN, Kenny AD. Acute effect of estradiol on the renal vitamin D hydroxylases in Japanese quail. Biochem Pharmacol. 1978; 27:2765-8. [PubMed: 216369]

45. Haddad JG, Chyu KJ. Competitive protein-binding radioassay for 25-hydroxycholecalciferol. J Clin Endocrinol Metab. 1971; 33:992-5. [PubMed: 4332615]

46. Hollis BW, Wagner CL, Drezner MK, Binkley NC. Circulating vitamin D3 and 25-hydroxyvitamin D in humans: an important tool to define adequate nutritional vitamin D status. J Steroid Biochem Mol Biol. 2007; 103:631-4. [PubMed: 17218096]

47. Zittermann A, Schleithoff SS, Koerfer R. Putting cardiovascular disease and vitamin D insufficiency into perspective. Br J Nutr. 2005; 94:483-92. [PubMed: 16197570]

48. Hollis BW. Circulating 25-hydroxyvitamin D levels indicative of vitamin D sufficiency: implications for establishing a new effective dietary intake recommendation for vitamin D. J Nutr. 2005; 135:317-22. [PubMed: 15671234]

49. Hollis BW, Wagner CL. Vitamin D deficiency during pregnancy: an ongoing epidemic. Am J Clin Nutr. 2006; 84:273. [PubMed: 16895872]

50. Dawodu A, Wagner CL. Mother-child vitamin D deficiency: an international perspective. Arch Dis Child. 2007; 92:737-40. [PubMed: 17715433]

51. Van der Meer IM, Karamali NS, Boeke AJ, et al. High prevalence of vitamin D deficiency in pregnant non-Western women in The Hague, Netherlands. Am J Clin Nutr. 2006; 84:350-9. [PubMed: 16895882]

52. Bassir M, Laborie S, Lapillonne A, Claris O, Chappuis MC, Salle BL. Vitamin D deficiency in Iranian mothers and their neonates: a pilot study. Acta Paediatr. 2001; 90:577-9. [PubMed: 11430721]

53. Markestad T, Elzouki A, Legnain M, Ulstein M, Aksnes L. Serum concentrations of vitamin D metabolites in maternal and umbilical cord blood of Libyan and Norwegian women. Hum Nutr Clin Nutr. 1984; 38:55-62. [PubMed: 6607243]

54. Sachan A, Gupta R, Das V, Agarwal A, Awasthi PK, Bhatia V. High prevalence of vitamin D deficiency among pregnant women and their newborns in northern India. Am J Clin Nutr. 2005; 81:1060-4. [PubMed: 15883429]

55. Lee JM, et al. Vitamin D deficiency in a healthy group of mothers and newborn infants. Clin Pediatr (Phila). 2007; 46:42-4. [PubMed: 17164508]

56. Hillman LS, Haddad JG. Perinatal vitamin D metabolism. III. Factors influencing late gestational human serum 25-hydroxyvitamin D. Am J Obstet Gynecol. 1976; 125:196-200. [PubMed: 1266899]

57. Nesby-O'Dell S, et al. Hypovitaminosis D prevalence and determinants among African American and white women of reproductive age: third National Health and Nutrition Examination Survey, 1988-1994. Am J Clin Nutr. 2002; 76:187-92. [PubMed: 12081833]

58. Bodnar LM, Catov JM, Roberts JM. Racial/ethnic differences in the monthly variation of preeclampsia incidence. Am J Obstet Gynecol. 2007; 196:324. e321-5. [PubMed: 17403406]

59. MacKay AP, Berg CJ, Atrash HK. Pregnancy-related mortality from preeclampsia and eclampsia. Obstet Gynecol. 2001; 97:533-8. [PubMed: 11275024]

60. Taufield PA, et al. Hypocalciuria in pre-eclampsia. N Engl J Med. 1987; 316:715-8. [PubMed: 3821810] 
61. Hulter HN, Melby JC, Peterson JC, Cooke CR. Chronic continuous PTH infusion results in hypertension in normal subjects. J Clin Hypertens. 1986; 2:360-70. [PubMed: 3543230]

62. Resnick LM, Laragh JH, Sealey JE, Alderman MH. Divalent cations in essential hypertension. Relations between serum ionized calcium, magnesium, and plasma renin activity. N Engl J Med. 1983; 309:888-91. [PubMed: 6350880]

63. Seely EW. Calciotropic hormones in pre-eclampsia: a renewal of interest. J Clin Endocrinol Metab. 2007; 92:3402-3. [PubMed: 17823275]

64. Bodnar LM, Catov JM, Simhan HN, Holick MF, Powers RW, Roberts JM. Maternal vitamin D deficiency increases the risk of preeclampsia. J Clin Endocrinol Metab. 2007; 92:3517-22. [PubMed: 17535985]

65. Olsen SF, Secher NJ. A possible preventive effect of low-dose fish oil on early delivery and preeclampsia: indications from a 50-year-old controlled trial. Br J Nutr. 1990; 64:599-609. [PubMed: 2265175]

66. Marya RK, Rathee S, Manrow M. Effect of calcium and vitamin D supplementation on toxaemia of pregnancy. Gynecol Obstet Invest. 1987; 24:38-42. [PubMed: 3623260]

67. Levine RJ, Hauth JC, Curet LB, et al. Trial of calcium to prevent preeclampsia. N Engl J Med. 1997; 337:69-76. [PubMed: 9211675]

68. Villar J, Abdel-Aleem H, Merialdi M, et al. World Health Organization randomized trial of calcium supplementation among low calcium intake pregnant women. Am J Obstet Gynecol. 2006; 194:639-49. [PubMed: 16522392]

69. Sabour H, Hossein-Nezhad A, Maghbooli Z, Madani F, Mir E, Larijani B. Relationship between pregnancy outcomes and maternal vitamin D and calcium intake: a cross-sectional study. Gynecol Endocrinol. 2006; 22:585-9. [PubMed: 17135038]

70. Scholl TO, Chen X. Vitamin D intake during pregnancy: association with maternal characteristics and infant birth weight. Early Hum Dev. 2009; 85:231-4. [PubMed: 19008055]

71. Brooke OG, Wood C. Growth in British Asians: longitudinal data in the first year. J Hum Nutr. 1980; 34:355-9. [PubMed: 7191436]

72. Brooke OG, Brown IR, Cleeve HJ, Sood A. Observations on the vitamin D state of pregnant Asian women in London. BJOG. 1981; 88:18-26.

73. Brooke OG, Butters F, Wood C. Intrauterine vitamin D nutrition and postnatal growth in Asian infants. BMJ (Clin Res Ed). 1981; 283:1024.

74. Mallet E, Gügi B, Brunelle P, Hénocq A, Basuyau JP, Lemeur H. Vitamin D supplementation in pregnancy: a controlled trial of two methods. Obstet Gynecol. 1986; 68:300-4. [PubMed: 3755517]

75. Mannion CA, Gray-Donald K, Koski KG. Association of low intake of milk and vitamin D during pregnancy with decreased birth weight. CMAJ. 2006; 174:1273-7. [PubMed: 16636326]

76. Olsen SF, Halldorsson TI, Willett WC, et al. Milk consumption during pregnancy is associated with increased infant size at birth: prospective cohort study. Am J Clin Nutr. 2007; 86:1104-10. [PubMed: 17921389]

77. Russell JG, Hill LF. True fetal rickets. Br J Radiol. 1974; 47:732-4. [PubMed: 4433986]

78. Orbak Z, Karacan M, Doneray H, Karakel-leoglu C. Congenital rickets presenting with hypocalcaemic seizures. West Indian Med J. 2007; 56:364-7. [PubMed: 18198743]

79. Specker BL, Ho ML, Oestreich A, et al. Prospective study of vitamin D supplementation and rickets in China. J Pediatr. 1992; 120:733-9. [PubMed: 1578308]

80. Weiler H, Fitzpatrick-Wong S, Veitch R, et al. Vitamin D deficiency and whole-body and femur bone mass relative to weight in healthy newborns. CMAJ. 2005; 172:757-61. [PubMed: 15767609]

81. Javaid MK, Crozier SR, Harvey NC, et al. Maternal vitamin D status during pregnancy and childhood bone mass at age 9 years: a longitudinal study. Lancet. 2006; 367:36-43. [PubMed: 16399151]

82. Reif S, Katzir Y, Eisenberg Z, Weisman Y. Serum 25-hydroxyvitamin D levels in congenital craniotabes. Acta Paediatr Scand. 1988; 77:167-8. [PubMed: 3369298] 
83. Congdon P, Horsman A, Kirby PA, Dibble J, Bashir T. Mineral content of the forearms of babies born to Asian and white mothers. BMJ (Clin Res Ed). 1983; 286:1233-5.

84. Hillman LS, Haddad JG. Human perinatal vitamin D metabolism: I, 25-hydroxyvitamin D in maternal and cord blood. J Pediatr. 1974; 84:742-9. [PubMed: 4820711]

85. Ala-Houhala M. 25-Hydroxyvitamin D levels during breast-feeding with or without maternal or infantile supplementation of vitamin D. J Pediatr Gastroenterol Nutr. 1985; 4:220-6. [PubMed: 3989622]

86. Salle BL, Glorieux FH, Lapillone A. Vitamin D status in breastfed term babies. Acta Paediatr. 1998; 87:726-7. [PubMed: 9722243]

87. Hollis BW, Roos BA, Draper HH, Lambert PW. Vitamin D and its metabolites in human and bovine milk. J Nutr. 1981; 111:1240-8. [PubMed: 6788913]

88. Camadoo L, Tibbott R, Isaza F. Maternal vitamin D deficiency associated with neonatal hypocalcaemic convulsions. Nutr J. 2007; 6:23. [PubMed: 17880694]

89. Oki J, Takedatsu M, Itoh J, Yano K, Cho K, Okuno A. Hypocalcemic focal seizures in a onemonth-old infant of a mother with a low circulating level of vitamin D. Brain Dev. 1991; 13:1324. [PubMed: 1892219]

90. Maiya S, Sullivan I, Allgroove J, et al. Hypocalcaemia and vitamin D deficiency: an important, but preventable, cause of life-threatening infant heart failure. Heart. 2008; 94:581-4. [PubMed: 17690157]

91. Kosecik M, Ertas T. Dilated cardiomyopathy due to nutritional vitamin D deficiency rickets. Pediatr Int. 2007; 49:397-9. [PubMed: 17532844]

92. Ward LM, Gaboury I, Ladhani M, Zlotkin S. Vitamin D-deficiency rickets among children in Canada. CMAJ. 2007; 177:161-6. [PubMed: 17600035]

93. Ladhani S, Srinivasan L, Buchanan C, All-grove J. Presentation of vitamin D deficiency. Arch Dis Child. 2004; 89:781-4. [PubMed: 15269083]

94. Dawodu A, Tsang R. Vitamin D deficiency and rickets: possible role of maternal vitamin D deficiency. Ann Trop Paediatr. 2007; 27:319. [PubMed: 18053352]

95. Hollis BW, Wagner CL. Vitamin D requirements during lactation: high-dose maternal supplementation as therapy to prevent hypovitaminosis D for both the mother and the nursing infant. Am J Clin Nutr. 2004; 80:1752S-8S. [PubMed: 15585800]

96. Litonjua AA, Weiss ST. Is vitamin D deficiency to blame for the asthma epidemic? J Allergy Clin Immunol. 2007; 120:1031-5. [PubMed: 17919705]

97. Wittke A, Chang A, Froicu M, et al. Vitamin D receptor expression by the lung micro-environment is required for maximal induction of lung inflammation. Arch Biochem Biophys. 2007; 460:30613. [PubMed: 17224129]

98. Poon AH, Laprise C, Lemire M, et al. Association of vitamin D receptor genetic variants with susceptibility to asthma and atopy. Am J Respir Crit Care Med. 2004; 170:967-73. [PubMed: 15282199]

99. Raby BA, Lazarus R, Silverman EK, et al. Association of vitamin D receptor gene polymorphisms with childhood and adult asthma. Am J Respir Crit Care Med. 2004; 170:1057-65. [PubMed: 15282200]

100. Cantorna MT, Zhu Y, Froicu M, Wittke A. Vitamin D status, 1,25-dihydroxyvitamin D3, and the immune system. Am J Clin Nutr. 2004; 80:1717S-20S. [PubMed: 15585793]

101. Cantorna MT. Vitamin D and its role in immunology: multiple sclerosis, and inflammatory bowel disease. Prog Biophys Mol Biol. 2006; 92:60-4. [PubMed: 16563470]

102. Banerjee A, Damera G, Bhandare R, et al. Vitamin D and glucocorticoids differentially modulate chemokine expression in human airway smooth muscle cells. Br J Pharmacol. 2008; 155:84-92. [PubMed: 18552877]

103. Song Y, Qi H, Wu C. Effect of 1,25-(OH)2D3 (a vitamin D analogue) on passively sensitized human airway smooth muscle cells. Respirology. 2007; 12:486-94. [PubMed: 17587413]

104. Nguyen M, Trubert CL, Rizk-Rabin M, et al. 1,25-Dihydroxyvitamin D3 and fetal lung maturation: immunogold detection of VDR expression in pneumocytes type II cells and effect on fructose 1,6 bisphosphatase. J Steroid Biochem Mol Biol. 2004; 89-90:93-7. 
105. Camargo CA Jr, Rifas-Shiman SL, Litonjua AA, et al. Maternal intake of vitamin D during pregnancy and risk of recurrent wheeze in children at 3 y of age. Am J Clin Nutr. 2007; 85:78895. [PubMed: 17344501]

106. Devereux G, et al. Maternal vitamin D intake during pregnancy and early childhood wheezing. Am J Clin Nutr. 2007; 85:853-9. [PubMed: 17344509]

107. Weiss ST, Litonjua AA. Childhood asthma is a fat-soluble vitamin deficiency disease. Clin Exp Allergy. 2008; 38:385-7. [PubMed: 18177489]

108. Podar T, Solntsev A, Karvonen M, et al. Increasing incidence of childhood-onset type I diabetes in 3 Baltic countries and Finland 1983-1998. Diabetologia. 2001; 44(suppl 3):B17-20. [PubMed: 11724410]

109. The EURODIAB Substudy 2 Study Group. Vitamin D supplement in early childhood and risk for type I (insulin-dependent) diabetes mellitus. Diabetologia. 1999; 42:51-4. [PubMed: 10027578]

110. Stene LC, Ulriksen J, Magnus P, Joner G. Use of cod liver oil during pregnancy associated with lower risk of type I diabetes in the offspring. Diabetologia. 2000; 43:1093-8. [PubMed: 11043854]

111. Hypponen E, Laara E, Reunanen A, Jarvelin MR, Virtanen SM. Intake of vitamin D and risk of type 1 diabetes: a birth-cohort study. Lancet. 2001; 358:1500-3. [PubMed: 11705562]

112. Cockburn F, Belton NR, Purvis RJ, et al. Maternal vitamin D intake and mineral metabolism in mothers and their newborn infants. BMJ. 1980; 281:11-4. [PubMed: 7407476]

113. Brooke OG, Brown IR, Bone CD, et al. Vitamin D supplements in pregnant Asian women: effects on calcium status and fetal growth. BMJ. 1980; 280:751-4. [PubMed: 6989438]

114. Vieth R, Chan PC, MacFarlane GD. Efficacy and safety of vitamin D3 intake exceeding the lowest observed adverse effect level. Am J Clin Nutr. 2001; 73:288-94. [PubMed: 11157326]

115. Heaney RP, Davies KM, Chen TC, Holick MF, Barger-Lux MJ. Human serum 25hydroxycholecalciferol response to extended oral dosing with cholecalciferol. Am J Clin Nutr. 2003; 77:204-10. [PubMed: 12499343] 


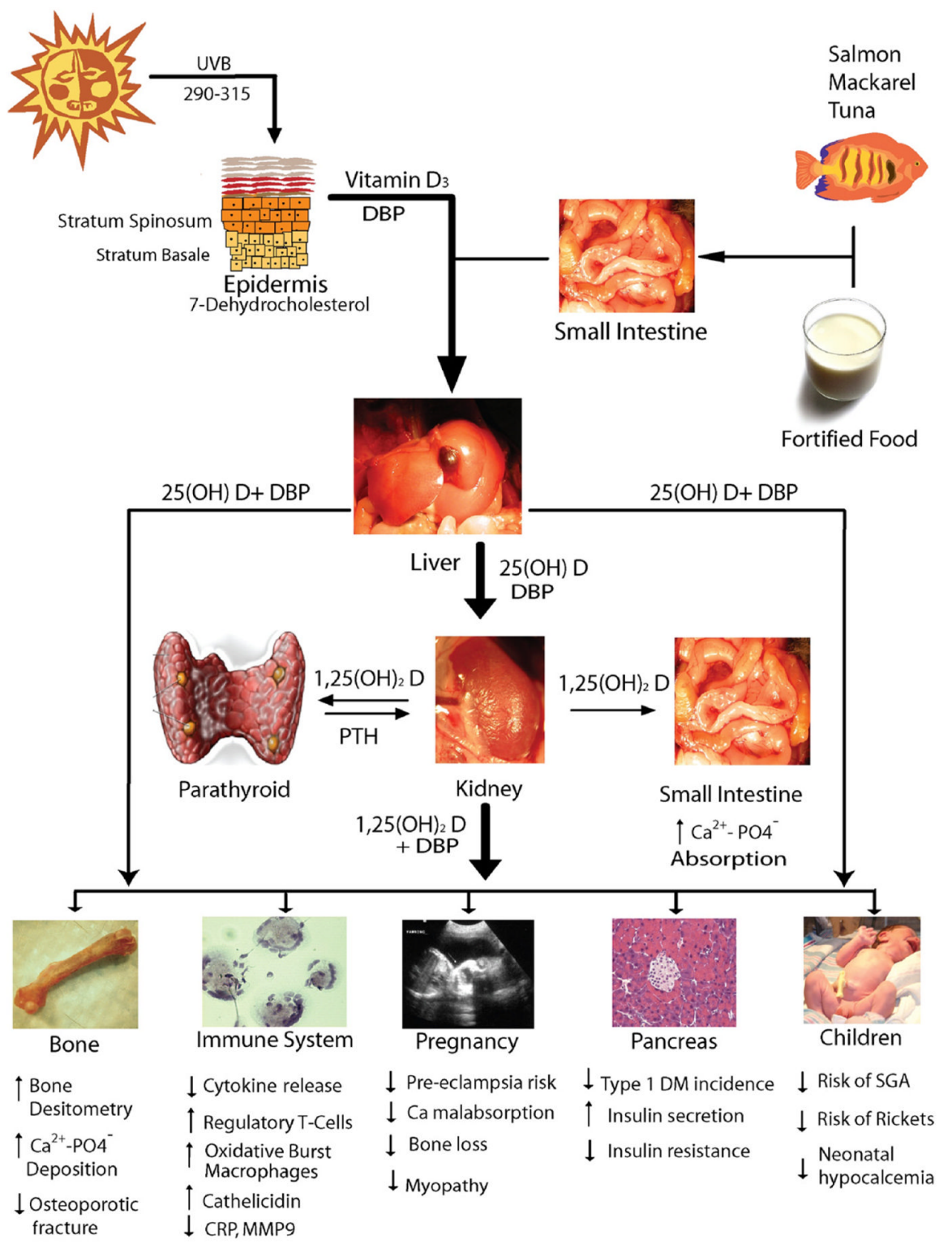

FIGURE. Vitamin D metabolism and tissue actions

$25(\mathrm{OH}) \mathrm{D}, 25$-hydroxy vitamin $\mathrm{D} ; \mathrm{Ca}^{2+}$, calcium; $C R P$, C-reactive protein; $D B P$, vitamin D binding protein; $D M$, diabetes mellitus; $M M P 9$, matrix metalloproteinase 9; $P O 4$, phosphate; $P T H$, parathyroid hormone; $S G A$, small for gestational age; $U V B$, ultraviolet B. 
TABLE 1

Vitamin D content

\begin{tabular}{|lc|}
\hline Source of vitamin D & Amount of vitamin D (IU) \\
\hline Cow's milk, fortified with vitamin D, 8 oz & 98 \\
\hline Soy milk, fortified with vitamin D, 8 oz & 100 \\
\hline Orange juice, fortified, 8 oz & 100 \\
\hline Cereal, fortified, 1 cup & $40-50$ \\
\hline Pink salmon, canned, 3 oz & 530 \\
\hline Sardines, canned, 3 oz & 231 \\
\hline Mackerel, 3 oz & 306 \\
\hline Herring, 3 oz & 1,383 \\
\hline Catfish, 3 oz & 425 \\
\hline Tuna, canned in oil, 3 oz & 200 \\
\hline Quaker Nutrition for Women Instant Oatmeal, 1 packet & 154 \\
\hline Egg yolk & 25 \\
\hline Most multivitamins & 400 \\
\hline Tri-Vi-Sol infant supplements, 1 drop & 400 \\
\hline Prenatal vitamins & 400 \\
\hline Over-the-counter vitamin $\mathrm{D}_{3}$ supplements & 2000 (max) \\
\hline Typical prescribed vitamin $\mathrm{D}_{2}$ supplements for deficiency & 50,000 (given weekly until replete) \\
\hline
\end{tabular}

Quaker; Quaker Oats Co, Chicago, IL. Tri-Vi-Sol; Mead Johnson Pharmaceuticals, Evansville, IN. 
TABLE 2

Risk factors for vitamin D deficiency

\begin{tabular}{|l|}
\hline Factor \\
\hline Northern latitudes, especially winter or spring \\
\hline Limited sun exposure \\
\hline Regular use of sunscreens \\
\hline African American or dark skin \\
\hline Obesity \\
\hline Extensive clothing cover \\
\hline Aging \\
\hline Malabsorptive syndromes (cystic fibrosis, cholestatic liver disease, inflammatory bowel disease, short gut syndrome) \\
\hline
\end{tabular}


TABLE 3

Stages of vitamin D deficiency and adverse effects

\begin{tabular}{|lcll|}
\hline Stage & Serum 25(OH)D, ng/mL & Maternal adverse effects & Newborn infant adverse effects \\
\hline Severe deficiency & $<10$ & $\begin{array}{l}\text { Increased risk of preeclampsia, } \\
\text { calcium malabsorption, bone loss, } \\
\text { poor weight gain, myopathy, higher } \\
\text { parathyroid hormone levels }\end{array}$ & $\begin{array}{l}\text { Small for gestational age, neonatal hypocalcemia, } \\
\text { hypocalcemic seizures, infantile heart failure, } \\
\text { enamel defects, large fontanelle, congenital } \\
\text { rickets, rickets of infancy if breastfed }\end{array}$ \\
\hline Insufficiency & $11-32$ & Bone loss, subclinical myopathy & $\begin{array}{l}\text { Neonatal hypocalcemia, reduced bone mineral } \\
\text { density, rickets of infancy if breastfed }\end{array}$ \\
\hline Adequacy & $32-100$ & $\begin{array}{l}\text { Adequate calcium balance, parathyroid } \\
\text { hormone levels }\end{array}$ & None, unless exclusively breastfed \\
\hline Toxicity & $>100$ & $\begin{array}{l}\text { Hypercalcemia, increased urine } \\
\text { calcium loss }\end{array}$ & Infantile idiopathic hypercalcemia \\
\hline
\end{tabular}

